\title{
Monochromatic light-emitting diode (LED) source in layers hens during the second production cycle
}

\author{
Rodrigo Borille ${ }^{1}$, Rodrigo G. Garcia ${ }^{1}$, Irenilza A. Nääs ${ }^{1}$, Fabiana R. Caldara ${ }^{1}$ \& Mayara R. Santana ${ }^{1}$ \\ ${ }^{1}$ Faculdade de Ciências Agrárias/Universidade Federal da Grande Dourados. Dourados, MS. E-mail: guigo_borille@hotmail.com; \\ rodrigogarcia@ufgd.edu.br; irenilza@gmail.com (Autora correspondente); fabianacaldara@ufgd.edu.br; mayara_mf@hotmail.com
}

\section{Key words:}

artificial lighting

egg production

color of light source

\begin{abstract}
A B S T R A C T
Light is an important environmental factor for birds, allowing not only their vision, but also influencing their physiological responses, such as behavioral and reproductive activity. The objective of this experiment was to evaluate the impact of different colors of monochromatic light (LED) sources in laying hens production during the second laying cycle. The study was conducted in an experimental laying house during 70 days. A total of 300 laying hens Isa Brown ${ }^{\circledR}$ genetic strain, aged 95 weeks, in the second laying cycle were used in the study. The artificial light sources used were blue, yellow, green, red and white. The light regimen was continuous illumination of $17 \mathrm{~h}$ per day (12 h natural and $5 \mathrm{~h}$ artificial) in a daily light regimen of 17L:5D (light: dark). The Latin Square design was adopted with five treatments (five colors) divided into five periods, and five boxes, with six replicates of ten birds in each box. The production and egg quality were evaluated. The different colors of light source did not affect production parameters or egg quality $(\mathrm{p}>0.05)$. The monochromatic light source may be considered as an alternative to artificial lighting in laying hens during the second production cycle.
\end{abstract}

\section{Palavras-chave:}

luz artificial produção de ovos cor de fonte luminosa

\section{Fonte monocromática diodo emissor de luz (LED) em galinhas poedeiras de segundo ciclo de produção}

\begin{abstract}
RES U M O
A luz é importante fator ambiental para aves permitindo não só a visão, mas também influenciando as respostas fisiológicas, como a atividade comportamental e reprodutiva. $\mathrm{O}$ objetivo deste experimento foi avaliar o impacto de diferentes cores de luz monocromática (LED) na produção de galinhas durante o segundo ciclo de postura. O estudo foi realizado em um galpão de postura experimental, durante 70 dias. Um total de 300 galinhas poedeiras da genética Isa Brown ${ }^{\circ}$, com idades de 95 semanas, no segundo ciclo de postura foi utilizado no estudo. As fontes de luz artificial utilizadas foram azul, amarelo, verde, vermelho e branco. O regime de luz era iluminação contínua de $17 \mathrm{~h}$ por dia ( $12 \mathrm{~h}$ natural: $5 \mathrm{~h}$ artificial), em regime de luz de 17L:7E (luz: escuridão). O delineamento estatístico adotado foi de quadrado latino, com cinco tratamentos (cinco cores), dividido em cinco períodos e cinco parcelas com seis repetições de dez aves em cada parcela. A produção e a qualidade dos ovos foram avaliadas. As diferentes cores de fonte de luz não afetaram os parâmetros de produção nem a qualidade dos ovos $(\mathrm{p}>0,05)$. A fonte monocromática de luz LED pode ser considerada uma alternativa para a iluminação artificial em galinhas poedeiras durante o segundo ciclo de produção.
\end{abstract}




\section{INTRODUCTION}

Light is an environmental factor extensively used to improve poultry production as it influences the physiological responses related to hens' reproduction and behavior (Rossi \& Pompei, 1995; Freitas et al., 2005; Deep et al., 2010). Reproductive performance of hens is dependent on the proper management of light, involving the quantity, the color and the frequency spectrum (Gongruttananun \& Guntapa, 2012). The birds' response to visible radiation has a peak on the yellowgreen bands of the light spectrum (545-575 nm), and it is responsible for their growth and behavior (Mobarkey et al., 2010). Gongruttananun (2011) found that the spectrum of red light accelerates sexual development. Artificial lighting system for laying hens using light emitting diodes is beneficial to the reduction of production costs (Gongruttananun \& Guntapa, 2012).

Light-emitting diode (LED) has been used worldwide in various areas, since it represents a financial benefit in reducing the costs (Taguchi, 2008). Several studies have been carried out in the use of LED in poultry production (Benson et al., 2013), including the use of different LED colors in the improvement of eggshell quality, in layers production (Er et al., 2007), and the enhancement of broilers' blood lymphocytes (Xie et al., 2008). LED is a semiconductor device that emits spatially incoherent light at a relative narrow frequency spectrum generated by an electroluminescence effect. The color of the bulb depends on the composition and condition of the applied semiconductor material and may range from ultraviolet to infrared (Carvalho, 2007). LEDs may be used up to 50,000 h, which much longer than incandescent and compact fluorescent lamps, whose life is 1,000 and $8,000 \mathrm{~h}$ of use, respectively (Taguchi, 2008).

Layers hens are often subjected to forced molting (Fassani et al., 2002; Souza et al., 2010) which is a procedure usually used in developing countries, in order to prevent the age related decline in egg yield and eggshell quality (Khan et al., 2011). Effectiveness of induced molting changes according to the methods, breed and age (Ocak et al., 2004). Egg weight, and the albumen index, yolk index and yolk color values are reported to increase gradually with hens' age (Borille et al., 2013) while some eggshell thickness decrease in older hens (Souza et al., 2010).

The objective of this study was to evaluate the use of different LED colors in artificial lighting in layers hens on egg yield and quality during the second production cycle.

\section{Material AND Methods}

The experiment was approved by the Universidade Federal da Grande Dourados - UFGD ethics committee (protocol \# $010 / 2013$ ), and it was conducted in the experimental poultry sector at the Faculdade de Ciências Agrárias, UFGD (latitude $23^{\circ} 28^{\prime} 28^{\prime \prime} \mathrm{S}$ and longitude $54^{\circ} 11^{\prime} 06^{\prime \prime} \mathrm{W}$ ) during the months from May to July, 2013. The study was divided into five periods of 14 days, being conducted in an open sided and naturally ventilated house, with polypropylene yellow lateral curtains.

A total of 300 commercial laying hens from Isa Brown genetic strain were reared in a three-tier cage system, equipped with trough feeders and nipple drinkers. Inside the house, five rooms were built in which six cages were placed with a capacity of 10 birds each, totaling six replicates each. The ambient was divided using plywood boards so that the artificial lighting of each light source tested did not interfere too much. The birds were reared and grown prior to the start of the experiment, using a regimen of $17 \mathrm{~h}$ of light per day (natural plus artificial light) with incandescent light bulbs (17L:7D; light: dark).

Moult by feeding hens with fodder containing 95\% of wheat bran was induced when they were 91 weeks old, as suggested by Biggs et al. (2003). Moulting period lasted 4 weeks for all groups, and during this time all hens were exposed to normal day lighting of $12 \mathrm{~h}$. After moulting hens were fed a diet based on corn and soybean meal, formulated according to the nutritional recommendations for Isa Brown layer hens.

The tested LED light sources were red $(600-630 \mathrm{~nm})$, white (2,800-3,200 K), blue (450-460 nm), yellow (580-590 nm), and green (510-530 nm). The wavelengths of LED colors were assessed using a meter (Chroma Meter CL 200, KonicaMinolta Sensing Inc., Osaka, Japan). The artificial lighting system of this experiment was connected to a timer in order to provide a continuous regimen of $17 \mathrm{~h}$ of light per day (in average of 12 $\mathrm{h}$ natural:5 $\mathrm{h}$ artificial LED light source), and $5 \mathrm{~h}$ of darkness (17L:5D; light: dark). Light intensity (20 lx) was standardized across all sources of light.

The experimental period was 14 days. Eggs were collected once daily at 10:00 h, and daily egg production $(\mathrm{P})$ was recorded and expressed as a percentage (\%). Eggs were weighed (EW) using a $0.01 \mathrm{~g}$-precision digital scale and egg mass (EM) was calculated as shown in Eq.1.

$$
\mathrm{EM}=\mathrm{P} \cdot \mathrm{EW}
$$

where:

$$
\begin{aligned}
& \text { EM - egg mass, g; } \\
& \text { P - egg production, \%; and } \\
& \text { EW - egg weight, g. }
\end{aligned}
$$

The average feed intake was calculated by the weight of the trough feeders, recorded in a spreadsheet and expressed in grams per bird per day $\left(\mathrm{g} \mathrm{bird}^{-1} \mathrm{~d}^{-1}\right)$.

On the last day of each experimental period (14 days), five intact eggs were randomly selected from each replicate $(50 \%$ of the eggs produced on that day), identified, and weighed (using a 0.01 g-precision digital scale). Those eggs were used to determine internal and external quality characteristics (egg specific gravity, eggshell thickness, albumen height). Egg specific gravity was determined using a saline solution (1060 to $1100 \mathrm{~g} \mathrm{~cm}^{-3}$ water) and albumen height was calculated by means of a digital caliper. Eggshell thickness was measured central region of the egg with the aid of a digital caliper. Both yolk weight and the shell weight were calculated as a percentage of egg. Haugh unit was calculated as shown in Eq. 2.

$$
\mathrm{UH}=100 \log \left[\mathrm{H}+7.57-1.7\left(\mathrm{EW}^{0.37}\right)\right]
$$

where:

$\mathrm{H}$ - albumen height, $\mathrm{mm}$; and 
EW - egg weight, according to Haugh (1937).

A Latin square design was adopted totaling five treatments (five LED colors), five boxes with six replicates of 10 birds each box, during five period of 14 days. Data were tested to normality and subjected to one-way analysis of variance (ANOVA) using the computational software Core Team ${ }^{\circ}$ (2012).

\section{Results AND Discussion}

No change in egg production was found $(\mathrm{p}=0.53)$ when layer hens were exposed to different LED colors (Table 1). Jácome et al. (2012) also observed that the LED colors did not affect the production indices of laying quails. Mobarkey et al. (2010) show that the peak sensitivity on the yellow-green bands of the light spectrum ( 545 to $575 \mathrm{~nm}$ ) might responsible for the growth and behavior of birds; however, it does not directly influence egg production.

The effect of these different colors was not found in the present study, probably because layer hens in the second production cycle are already adapted to the light stimulus produced by the light source, which emits a broad spectrum of lighting. Studying the impact of light on egg production (using natural light, LED red, and fluorescent lamp with LED red) Gongruttananun (2011) found that layers exposed to fluorescent lamp with LED red, and LED red alone began the laying period earlier than the treatment with natural light, indicating that the red color might impact the total egg production of layer hens. Similarly, Kim et al. (2010) found an increase in the production of eggs and ovarian weight in birds exposed to red LED and the authors indicate that the spectrum of red color accelerates sexual development (Huber-Eicher et al., 2013).

The results of average egg weight were similar $(\mathrm{p}=0.73$, Table 1). In a study conducted by Gongruttananun \& Guntapa (2012) the use of red LED did not affect egg weight and quality. Studying the impact of different LED colors in comparison with the incandescent light bulb on performance of layer quails Jacome et al. (2012) found no influence of color on the egg weight, in agreement with the results found in the present study. However, Er et al. (2007) indicate that the use of LED red might increase the egg weight. Contradiction on the different results indicates that this subject should be further investigated.

Mean feed intake did not differ $(p=0.35)$ between treatments (Table 1). Similar results were found by Jacome

Table 1. Egg yield per day per housed bird in 14 days (Prod, $\%)$, average egg weight (EW), feed consumption per bird per day $(\mathrm{FC} / \mathrm{B} / \mathrm{D})$, and egg mass $(\mathrm{EM})$ of hens exposed to LED lighting

\begin{tabular}{lcccc}
\hline $\begin{array}{c}\text { LED } \\
\text { color }\end{array}$ & $\begin{array}{c}\text { Prod } \\
\text { (\%) }\end{array}$ & EW & FC/B/D & EM \\
Red & $73.04 \pm 2.56$ & $66.46 \pm 1.62$ & $0.112 \pm 0.06$ & $48.80 \pm 1.62$ \\
White & $73.07 \pm 2.19$ & $66.90 \pm 1.12$ & $0.112 \pm 0.01$ & $48.81 \pm 1.12$ \\
Blue & $72.16 \pm 3.34$ & $66.57 \pm 1.64$ & $0.111 \pm 0.04$ & $47.94 \pm 1.64$ \\
Yellow & $72.66 \pm 2.01$ & $66.62 \pm 1.33$ & $0.112 \pm 0.04$ & $48.43 \pm 1.33$ \\
Green & $74.69 \pm 1.62$ & $67.46 \pm 1.62$ & $0.114 \pm 0.05$ & $49.80 \pm 1.62$ \\
p-value & 0.53 & 0.73 & 0.35 & 0.42 \\
\hline
\end{tabular}

Anova results $(p>0.05)$, ${ }^{ \pm}$standard error et al. (2012) which, in addition to evaluate feed intake, of laying quails also investigated the frequency of accesses to the feeders when subjected to artificial lighting with different LED color and incandescent lamps. The authors found that the birds presented more access to feeders in ambient with incandescent lamp and blue LED than in ambient with other tested light sources. Gongruttananun (2011) did not find a difference on feed intake in the experiment with different light sources. However, Gongruttananun \& Guntapa (2012) found improvement in feed conversion ratio of birds exposed to natural light and red LED complemented with red LED, when compared to the use of natural light. Min et al. (2012) reported decreasing in feed conversion of hens reared under LED red light source.

Egg mass did not differ among treatments $(p=0.42$; Table 1). Layer hens in the second cycle usually reduce eggs production and egg quality. Albumen height did not differ ( $\mathrm{p}$ $>0.05$ ) between treatments (Table 2).

The albumen height is generally affected by the age of the birds, the storage time and environmental variables, tending to decrease with increasing age of hen and the egg storage time. The average of the Haugh (Table 2) did not differ between treatments. Similar results were found by Gongruttananun \& Guntapa (2012) in an experiment using LED light red color and natural light. Eggshell quality was assessed by the eggs specific gravity, and it remained similar between different LED colors ( $\mathrm{p}=0.390$; Table 2$)$. In a previous study by Gongruttananun (2011), the structure of the eggshell was not affected by the LED light red, with similar results from the present research. However, Er et al. (2007) found differences in shell quality of eggs from laying hens exposed to monochromatic light in red, green and blue colors, when compared to incandescent lamps. The authors stated that the peel strength was higher for the egg from the green light treatment, when compared to other treatments. Other authors claim that the LED red color light sources lead to improvement in the eggshell thickness (Min et al., 2012; Kim et al., 2010).

The composition of each component of the egg (albumen percentage, percentage of yolk and eggshell percent) did not differ ( $p \geq 0.05$ ) between the LED colors tested (Table 3 ). The results might be associated to other factors such as the age of the birds, management and rearing environment and these factors may affect the composition and structure of laid eggs. The molting process affects the birds' physiology and thus it reflects the final response of egg production (Rossi \& Pompei, 1995).

Table 2. Albumen height (AH), Haugh unit (HU), specific gravity (SG), eggshell thickness (ET) of eggs from hens exposed to LED lighting

\begin{tabular}{lcccc}
\hline $\begin{array}{c}\text { LED } \\
\text { Color }\end{array}$ & AH & HU & SG & ET \\
Red & $7.40 \pm 0.29$ & $82.67 \pm 1.72$ & $1081.4 \pm 2.63$ & $0.251 \pm 0.07$ \\
White & $7.37 \pm 0.16$ & $82.53 \pm 1.09$ & $1081.6 \pm 1.21$ & $0.248 \pm 0.07$ \\
Blue & $7.34 \pm 0.20$ & $82.27 \pm 1.06$ & $1082.1 \pm 0.83$ & $0.250 \pm 0.01$ \\
Yellow & $7.52 \pm 0.12$ & $83.75 \pm 1.21$ & $1080.5 \pm 6.61$ & $0.233 \pm 0.01$ \\
Green & $7.63 \pm 0.13$ & $84.10 \pm 0.81$ & $1081.3 \pm 1.26$ & $0.249 \pm 0.05$ \\
p-value & 0.72 & 0.68 & 0.40 & 0.390 \\
\hline
\end{tabular}

Anova results $(p>0.05),{ }^{ \pm}$standard error 
Table 3. Percentage ratio of the components of the eggs percentage of albumen (Alb \%), yolk percentage ( $\mathrm{Y} \%$ ), and the percentage of eggshell (ES \%) of hens exposed to LED lighting

\begin{tabular}{lccc}
\hline LED & Alb & $\mathbf{Y}$ & ES \\
\cline { 2 - 4 } Color & & $\mathbf{( \% )}$ & \\
Red & $64.30 \pm 1.14$ & $25.36 \pm 0.62$ & $10.32 \pm 0.87$ \\
White & $65.44 \pm 0.50$ & $25.07 \pm 0.49$ & $9.48 \pm 0.29$ \\
Blue & $65.09 \pm 0.37$ & $25.41 \pm 0.22$ & $9.49 \pm 0.21$ \\
Yellow & $64.98 \pm 0.28$ & $25.68 \pm 0.38$ & $9.32 \pm 0.20$ \\
Green & $65.18 \pm 0.71$ & $25.55 \pm 0.33$ & $9.25 \pm 0.33$ \\
p-value & 0.80 & 0.68 & 0.58 \\
\hline
\end{tabular}

Anova results $(p>0.05),{ }^{ \pm}$standard error

Further studies are needed to identify the economic advantages in using LED lighting in rearing environment of laying hens, since the use of this light source does not impact in egg production and quality.

\section{Conclusions}

1. The use of different colors of LED light sources used in rearing ambient of layer hens in the second cycle did not affect their egg production.

2. No impact in the egg quality was found in hens exposed to different LED colors.

\section{ACKNOWLEDGements}

To CAPES and CNPq for the scholarship and financial support.

\section{Literature Cited}

Benson, E. R.; Hougentogler, D. P.; McGurk, J.; Herrman, E.; Alphin, R. L. Durability of incandescent, compact fluorescent, and light emitting diode lamps in poultry conditions. Applied Engineering in Agriculture, v.29, p.103-111, 2013. http://dx.doi. org/10.13031/2013.42531

Biggs, P. E.; Douglas, M.W.; Koelkebeck, K.W.; Parsons, C. M. Evaluation of nonfeed removal methods for molting programs. Poultry Science, v.82, p.749-753, 2003. http://dx.doi.org/10.1093/ ps/82.5.749

Borille, R.; Garcia, R. G.; Royer, A. F.; Santana, M. R.; Colet, S.; Nääs, I. A.; Caldara, F. R.; Almeida Paz, I. C. L.; Rosa, E. S.; Castilho, V. A. R. The use of light-emitting diodes (LED) in commercial layer production. Brazilian Journal of Poultry Science, v.15, p.135-140, 2013. http://dx.doi.org/10.1590/s1516-635x2013000200009

Carvalho, H. M. B. Diodos emissores de luz de alto brilho e alta potência (artigo DL-05). São Carlos: Directlight. 2007. 25p.

Core Team.A language and environment for statistical computing. R Foundation for Statistical Computing, 2012, Vienna, Austria.<httpp.//www.R-project.org/>Oct.10 2012.

Deep. A.; Schwean-Lardner, K.; Crowe, T. G.; Fancher, B. I.; Classen, H. L. Effect of light intensity on broiler production, processing characteristics, and welfare. Poultry Science, v.89, p.2326-2333, 2010. http://dx.doi.org/10.3382/ps.2010-00964

Er, D.; Wang, Z.; Cao, J.; Chen, Y. Effect of monochromatic light on the egg quality of laying hens. Journal of Applied Poultry Research, v.16, p.605-612, 2007. http://dx.doi.org/10.3382/japr.2006-00096
Fassani, E. J.; Bertechini, A. G.; Brito, J. A. G.; Kato, R. K.; Geraldo, A. Utilization of different levels of sodium supplementation for commercial laying hens on second cycle of production. Brazilian Journal of Poultry Science, v.4, p.235-241, 2002.

Freitas, H. J.; Cotta, J. T. B.; Oliveira,A. I. G.; Gewher, C. E. Evaluation of lightning programs upon the performance of white egg layers. Ciência e Agrotecnologia, v.29, p.424-428, 2005. http://dx.doi. org/10.1590/S1413-70542005000200021

Gongruttananun, N. Influence of red light on reproductive performance, eggshell ultrastructure, and eye morphology in Thai-native hens. Poultry Science, v.90, p.2855-2863, 2011. http:// dx.doi.org/10.3382/ps.2011-01652

Gongruttananun, N.; Guntapa, P. Effects of red light illumination on productivity, fertility,hatchability and energy efficiency of Thai indigenous hens. Kasetsart Journal Natural Science, v.46, p.51-63, 2012.

Haugh, R. R. The Haugh unit for measuring egg quality. US Egg Poultry Magazine, v.43, p.552-555, 1937.

Huber-Eicher, B.; Suter, A.; Spring-Stahli, P. Effects of colored lightemitting diode illumination on behavior and performance of laying hens. Poultry Science, v.92, p.869-873, 2013. http://dx.doi. org/10.3382/ps.2012-02679

Jácome, I. M. D. T.; Borille, R.; Rossi, L. A. Desempenho produtivo de codornas alojadas em diferentes sistemas de iluminação artificial. Archivo de Zootecnia, v.61, p.449-456, 2012. http:// dx.doi.org/10.4321/S0004-05922012000300013

Khan, R. U.; Nikousefat, Z.; Javdani, M.; Tufarelli, V.; Laudadio, V. Zinc-induced moulting: production and physiology. World's Poultry Science Journal, v.67, p.497-506, 2011. http://dx.doi. org/10.1017/S0043933911000547

Kim, M. J.; Choi, H. C.;Suh, O. S. A study of different sources and wavelengths of light on laying egg characteristics in laying hens. Korean Journal of Poultry Science, v.37, p.383-388, 2010. http:// dx.doi.org/10.5536/KJPS.2010.37.4.383

Min, J. K.; Hossan, M. S.; Nazma, A. Effect of monochromatic light on sexual maturity, production performance and egg quality of laying hens. Avian Biology Research, v.5, p 69-74, 2012. http:// dx.doi.org/10.3184/175815512X13350270679453

Mobarkey, N.; Avital, N.; Heiblum, R.; Rozenboim, I. The role of retinal and extra-retinal photostimulation in reproductive activity in broiler breeder hens. Domestic Animal Endocrinology, v.38, p.235243, 2010. http://dx.doi.org/10.1016/j.domaniend.2009.11.002

Ocak, N.; Sarica, M.; Erener, G.; Garipoglu, A. V. The effect of body weight prior to molting in brown laying hens on egg yield and quality during second production cycle. International Journal of Poultry Science, v.3, p.768-772, 2004. http://dx.doi.org/10.3923/ ijps.2004.768.772

Rossi, M.; Pompei, C. Changes in some egg components and analytical values due to hen age. Poultry Science, v.74, p.152-160, 1995. http://dx.doi.org/10.3382/ps.0740152

Souza, K. M. R.; Carrijo, A. S.; Allaman, I. B.; Fascina, V. B.; Mauad, J. R. C.; Suzuki, F. M. Métodos alternativos de restrição alimentar na muda forçada de poedeiras comerciais. Revista Brasileira Zootecnia, v.39, p.356-362, 2010. http://dx.doi.org/10.1590/ S1516-35982010000200019 
Taguchi, T. Present status of energy saving technologies and future prospect in white LED lighting. IEEJ Transactions on Electrical and Electronic Engineering, v.3, p.21-26, 2008. http://dx.doi. org/10.1002/tee. 20228
Xie, D. Z.; Wang, X.; Dong, Y. L.; Cao, J.; Wang, J. F.; Chen,J. L.; Chen, Y. X. Effects of monochromatic light on immune response of broilers. Poultry Science, v.87, p.1535-1539, 2008. http://dx.doi. org/10.3382/ps.2007-00317 